\title{
Concept of "City" in the Kazakh Poetic Texts
}

\author{
Almagul Sovetovna Adilova ${ }^{1}$, Baglan Satibekovna Kaukerdekova ${ }^{2}$, Zamzagul Nagashybaevna Zhuyntaeva $^{1}$, \\ Ainagul Zikirovna Kazanbayeva ${ }^{1}$ \& Elvira Nasipkulovna Azharbekova ${ }^{1}$ \\ ${ }^{1}$ The Karaganda State Universityof the name of academician Y. A. Buketov, Karaganda, Kazakhstan \\ ${ }^{2}$ Karaganda university of Bolashak, Karaganda, Kazakhstan \\ Correspondence: A. Adilova, Universitetskaya St., 28, Karaganda, 100028, Kazakhstan.
}

Received: February 28, 2015 Accepted: March 20, 2015 Online Published: April 24, 2015

doi:10.5539/res.v7n6p146 URL: http://dx.doi.org/10.5539/res.v7n6p146

\begin{abstract}
In the literary artistic process of Kazakhstan, where bilingualism is observed, the image of the city is interpreted from different points - the urban and traditional. The basic concept of "steppe", displaying the key concepts of the national mentality, are based on the peculiarities of the geographical area, natural resource use, lifestyle of the Kazakh people, a way of managing economy. Urbanistic processes that changed the space of Kazakhs led to certain changes in the perception of the world, its evaluation. This is related to changes in the national consciousness, which was formed over thousands of years of nomadic life. Therefore, in the mentality of poets who preserved the spirit of the nomads, the city is represented in two ways, opposed to the steppe, embodying all the best in the behavior, character and emotional sphere of the people.
\end{abstract}

Keywords: kontseptosfer, urbanistic processes, national mentality, transformation, concept, interpretation, steppe, city, perception, assessment

\section{Introduction}

Kazakhstan, is a country of nomads in the past that have fallen to the urban way of life in the twentieth century, under the Soviet civilization. For various reasons (closest proximity to Russia geographically, common history with a unified political system, the relocation of many people in Kazakhstan) Kazakhstan is a country within the linguistic and cultural space of which bilingualism coexists. In this regard, an important place in the literary artistic process belongs to both poets and writers writing in their native Kazakh language and bilingual writers speaking Kazakh and Russian languages, however, reflecting perceptions and understanding of contemporary life and culture from different angles - urban and traditional.

Renowned scientist G. Gachev in the introduction of his book, devoted to the description of national images of the world of Central Asian people, i.e. Kazakhs and Kyrgyz, writes: "Nature, where people live here is the vast steppes, deserts and mountains. So life, lifestyle and worldview of a nomad, farmer and mountaineer can be understood and reflected here. But a defining print is imposed by a source, namely nomadic lifestyle (Gachev, 2002), and this is a philosophical outlook on life, courage (required in the defense of one's space), breadth of the soul, respect to any person, interrelatedness of man and the world, perception of man as a particle of the universe, the cult of the word (sozge toktau - when akyns, poets compete, one who notices the superiority of his opponent stops aitys), freedom of speech (both nobleman and common people could talk to khan), communication.

Transition from a nomadic to a settled way of life has been very painful, and it was one of the causes of poetry "Zar Zaman" (sad poetry) - (Dosmukhamedov, 1928, 1991). Therefore, for "Zar Zaman" poets, whose works contained nostalgia for the past days, discontent and fear of the future, city, fortress, mound building was alien, i.e. it was not native, but alien, which led to a transformation of the national mentality (Kamzabekuly et al., 2013). All that is lost and accepted in the result of the transition to a sedentary lifestyle is sharply contrasted and evoke strong emotions in the perception by poets. Contemporary poets has the same outlooks.

According to cultural studies scholar Nogerbekov B.: "The City and aul (the village) - it's almost two different information fields, two subcultures. Typically, the Kazakh-language population, are mostly residents of the villages, watch the Kazakh media, read the works of Kazakh writers, listen to the Kazakh songs, etc., while the Russian-speaking city dwellers prefer local Russian-speaking and/or Russian/foreign media reports, the Russian-language/foreign literature and music. However, this is not the absolute truth, because there are Kazakh-indigenous city dwellers and Russian-speaking representatives who live in villages, but the fact of influence 
of subcultures is undeniable" (Nogerbekov, 2010).These differences are reflected in the change of mentality of the Kazakhs, which was formed for the most part due to the nomadic way of life along the boundless steppes.

\section{Methods}

Kazakh literature, as well as any national literature, is a part of semiosphere of the world culture, has a versatile impact on the inner world, the state of mind of people, enriches their spirituality, points ways to improve personal qualities. Literary texts reflect various changes occurring in the life of society, which have an impact on the attitudes, perception, evaluation and emotional state of people and how this effect in many cases leads to disastrous consequences. From this point of view, poetic texts are of great interest as poetry, according to Phateyeva, "is a kind of speech for yourself", where another person is needed only as an intermediary to communicate with oneself or with the world" (Phateyeva, 1995) where he encodes definite meanings.

Methods of contextual, cognitive-psychological, stylistic analysis are used and techniques of linguistic and cultural description are applied in the work.

\section{Results}

The concept of "steppe", reflecting the key concepts of the national mentality, is used to transfer the conceptual and substantive information that is understandable and close to the reader, due to the peculiarities of the geographical area, natural resource use, lifestyle of the Kazakh people, a way of managing economy.

Urbanistic processes that changed the space of Kazakhs led to certain changes in the perception of the world, its evaluation. This is related to changes in the national consciousness, which was formed over thousands of years of nomadic life. Therefore, in the mentality of poets who preserved the spirit of the nomads, the city is represented in two ways, opposed to the steppe, embodying all the best in the behavior, character and emotional sphere of the people.

\section{Discussion}

The richness of each national language is determined not only by the presence of an extensive vocabulary, grammatical features, but also by the conceptual sphere, forming the corresponding language personality.

"The structure of the conceptual sphere consists of a core (cognitive-propositional structure of the concept), circumnuclear zone (other lexical representations of an important concept, its synonyms, etc.) and the periphery (associative and figurative representations). The core and circumnuclear zone mainly represent universal and common knowledge, and periphery individual) "(Stepanov, 1997; Maslova, 2008).

The concept allows us to transfer gained knowledge into a new situation and comprehend new information based on the already existing meanings of the words.

According to many researchers lexis is important to distinguish and study because in the conceptual system of language main constituents are the concepts that are close with "semantic parts of speech", the concepts of the object and its parts, motion, action, place or space, time, sign (Gackendorff, 1993).

According to V. A. Maslova "concept has a complex structure consisting of a socio-psycho-cultural part besides conceptual, which is not much thought by the native speaker as it is experienced by him, it includes associations, emotions, evaluations, national images and connotations inherent in the given culture (Maslova, 2008). Therefore, in contrast to the Russian poets, whose characteristic feature is "marine complex" (Phateyeva, 2004), vocabulary verbalizing the concept of "steppe" is always of great importance for Kazakh writers and poets. The complex structure of the concept allows us to describe and interpret the cognitive features of a various nature, i.e. the core and the periphery of the basic concept.

According to Z. Balmagambetova, "the structure of the concept consists of 3 components: subject-figurative, conceptual and evaluative components, or in another interpretation: the cultural concept consists of the core (encoding image of the universal subject code (USC), the basic component (set of cognitive segments and cognitive signs forming them) and the periphery - interpretative field" (Balmagambetova, 2013).

Scholars have different opinions on the number of concepts. According to A. Wierzbicka there are three concepts in the Russian language, Destiny, Longing, Will (Wierzbicka, 1996). Y. S. Stepanov, who has systemized constants of the Russian culture, points their number to 50 and basic among them are "Truth", "Law", "Love", "Word", "Soul", "Sin" and others. (Stepanov, 1997). Knowledge engineer V. A. Maslova considers that there are several hundred of them (Maslova, 2008).

There are two groups of concepts - cognitive and artistic. Artistic concept is created under the influence of personal interpretation of the meaning of words and is a bunch of representations, feelings, emotions arising in 
an associative way.

Every new appeal to the artistic text is a "non-canonical speech situation" (Paducheva, 1996), when there is a new addressee, perceiv and interpret cultural and emotional experience of the poet, therefore suggests compassion and sympathy.

A writer Tursyn Zhurtbay transfers amazement, admiration, jealousy, regret of his hero, a native of the indigenous China, traveling round Kazakhstan with his chimpanzee in search of work at the sight of the Kazakh steppe: "He first admired such a beautiful, endless and carefree phenomenon. And having seen folk festivities that are full of dignity and joy, self-esteem, love for one another, uttered: That's what a width is!" Although such an evaluation is expressed by a stranger, Kazakhs themselves also admired and were proud of their endless steppe, loved and protected it.

Width of the steppe, its variety of colours influenced on the formation of the national character, behavior, moral and ethical creed, mentality, figurative thinking and historical experience of the people, These qualities were once marked by a participant of the Polish uprising of 1830-1831, revolutionary Yanushkevich, who wrote: "I am more and more convinced that the Kyrgyz (Kazakh) people are of great intelligence. What's the ease of speech, as everyone can explain his business and argue skillfully against his opponent. Even children's mind develops quickly" (Yanushkevich, 2006). Words function as a means of expression of previously interpreted images and the author's intention in a figurative thinking.

The openness of nature, generosity, delicacy of feelings, spiritual wealth, aptitude, eloquence, courage, poetic thinking, honesty, conscientiousness, rebelliousness, benevolence to everyone, even to a stranger, peacefulness, kindness, generosity, punctuality, willingness to help all, firmness of words and loyalty to his promise, i.e., all the qualities that are inherent in nomads living in the vast steppe, with increasing urbanization began to decrease.

Lexicographical data of the Kazakh and Russian languages are different: City — "the largest settlement with the administrative, cultural institutions and industrial enterprises" (Dictionary of the Kazakh language, 1999): 1) The largest settlement, administrative, commercial, industrial and cultural center. 2) The central part of the settlement, in contrast to the outskirts and suburbs. 3) In the old days in Rus: shielded by a wall settlement. 4) Units. Urban areas as opposed to rural, rustic. 5) In the game of "town": playground where figures of the towns are placed (Ozhegov \& Shvedova, 1999), and the Kazakh-Russian dictionary shows five meanings of the word (Kazakh-Russian, 2008). The analysis of the factual material indicates that mainly one meaning is used in the literary text, i.e., city is home to people, particular settlement inhabited by indigenous residents and visitors. In this regard, city is one's or someone else's space, it is unfamiliar and dangerous space, and is represented as an artifact and a living creature.

The concept of "city" as one of the most important components of the super concept "space" is reflected in the individual and collective language pictures of the world, being the basis of individual and social consciousness. Artistic picture of the world, belonging to the individual language picture of the world is a view of the world which is embodied in the language of works of literary artists.

Life in the big city and its vanity, rigid boundaries of space, frames in the manifestation of different emotions and behavior, adaptation to an unfamiliar culture, the loss of traditional views on many things - all this left an imprint on the behavior and character of the man who lives there: generosity acquired distorted features, suspiciousness towards another person appeared - the doors were locked, feelings have lost their bygone openness and beauty, absolute promptness, optionality, volatility that led to the downfall of morals appeared. All this were writhed with Kazakh poets and writers and was reflected in literary texts of the Soviet period and modernity.

The image of the city, its perception, its impact on the emotional state of mind of poets and writers are considered and studied in Russian linguistics and literary studies, particularly in the scientific world it is well-known "Petersburg text". For objective reasons for the Kazakh people the image of the city is not so attractive and familiar, as for residents of the European part of the world.

In the texts created by writers before Independence, the city and the perception of it by authors are mainly verbalized positively, it is primarily related to Almaty, Kazakhstan's capital of that time. This city, where according to the statistics, up to the 1980 s, at most $10-15 \%$ of Kazakhs lived (Sattarov, 2014), attracted all Kazakh writers: Alystan angsatip koigani, Ati bal siakti Almaty (word-for-word translation: Makes me long for it from distance, Almaty the name of which is like honey) (Aisulu Rustemova) i.e., it is "virtuous city" for them. According to the great Al-Farabi it's "like a perfectly healthy body, all the organs of which help each other in 
order to save the life of a living creature and make it more complete" and the extrapolation of his characteristics of the head of the city towards the residents allows us to create the expectation of the most ordinary people, who inhabit any city: "has to possess all the virtues - health, keen intellect, conscience, knowledge and gentle attitude to his citizens" (Al-Farabi, 1970). Romantic attitude to life, environment, a sense of confidence in oneself and others, mutual understanding caused by this are verbalized in a positive light.

Lexical-semantic analysis of a series of poems of poets shows sublime attitude to this inaccessible, beautiful city that has become the personification of the state and the people. For example, Abdilda Tazhibayev, a prominent poet of the Soviet period, calls it a city where golden-haired poplars reach for the sky, where the rainbow stretches its arms to all, like Kazakh dastarkhan, covered with love for friends (1957). Poet-soldier Kasim Amanzholov, who was unable to obtain any residence or apartment in this city, called it a golden cradle, golden nest, a paradise, which was dreamed by our ancestors since ancient times, a beautiful far, but with changeable weather $(1945,1953)$. Mukagali Makatayev a poet loved by the current generation of readers as well who began writing in the early 60's of the last century, sees festive Almaty as a blushed steppe and night citylife as a tender bride-girl with a magic aureole, core of high mountains. And Kulyash Akhmetova, a representative of the next generation, that is, who came into the literature in the 70s, describes it as a flourishing, free, pampered, shining with honor and nobility maiden. Meanings of these linguistic units - words, idioms, free phrases, sentences - are associated with the steppe, although not included in the content of the concept, i.e. only describe it: steppe - golden cradle, dastarkhan is always wide, steppe stretches to the sky (horizon), i.e., no space limitations. This is primarily because many poets and writers are proud of the very fact of having such a beautiful city, dream city that meets global standards.

In the 80 's the evaluation of the city begins to show alarming notes that indicate the ambiguity of Almaty's perception: opposition of the city and the village, symbolizing the steppe emerges. This perception, evaluation, interpretation of the image of the city is displayed in the poetic texts reflecting different emotional states of the masters of the pen at different times of day and year.

This is the time when poets felt infringement and extrusion by the city of the conventional values of the steppe, strengthened by stagnant socialism, which was reflected in hard-hitting actions of chauvinist officials at different levels, beginning from consumer and ending with party. Rejection of such a transformation was reflected in fiction as well, the perception is gradually changing in the direction of uncertainty, it is blurry, so Saken Imanasov writes that Almaty has become expensive, haughty, mysterious.

Over time, creative people in the city began to feel that they have become redundant; become aware of their irrelevance, their inaptitude in the bustle of the metropolis, that's why the city seemed to Ulukbek Yesdauletov as a secret world, buried under the eagle that hatched it and suffocating its poetic soul. This negative perception is strongly transferred by the poet Serik Aksunkaruly living in the province and often visiting the capital, which was called by him as the insincere, deceptive, changeable, filthy city. He perceives the city as the hated civilization that buried the steppe.

Year after year the negative emotional colouring and connotation of the words, verbalizing city strengthens. One of the most famous and talented Kazakh poets Gulnar Salykbayeva characterizes the city as a windy cold, cruel murderer, snow, beggar, desolate steppe, ghost-fog, grey cloud, black vessel, uncertainty city, a silent distance, restless, beautiful city in a dream and faded in reality, yellow from melancholy, stone city, deserted streets, exhausted city, an endless stream, indifferent city. The lexicon of these poets verbalize some additional features related in an associative way with other lexical units that convey sadness over the steppe: steppe-silent distance, yellow steppe-Saryarka, faded steppe, desert steppe, etc.

Gradually a sense of nostalgia for the steppe, aul (village) emerges, leading to a change in the emotional state of those living in the city, to the opposition of the urban and rural landscapes, bustle and regularity, noise and serenity, dissatisfaction of themselves and others and peace of mind: steppe - a mother, a poem (epos), courage, nobility of sons, width, grandeur, beauty, Abay (Aksunkaruly); aul (village)—dreams, mother, sweet childhood (Salykbayeva); aul (village)—generosity of the soul, scarlet field, child's babble, mother's lullaby (Sagyntayuly).

One of the modern poets Yesenkul Zhakupbekov, who had no place in the southern, sunny city that has lost its status as the state capital calls Almaty a knight-city, crank city, a friend with a book in his hand, a blank sheet of dreams, a paradise garden of poets, soul of the Kazakh, who suffered innocently and slandered, the capital of poetry, trying to surprise with its wealth and yet remaining holy for the whole life. Such a paradoxical conclusion is observed in many writers and poets.

In the texts of poets Serik Sagyntayuly and Bauyrzhan Haliolla belonging to the younger generation, the city and the village are opposed as a part of the steppe. Poems of these poets are penetrated by sinking feeling of longing 
for the lost values, the loss of which is inevitable in the process of urbanization, the sense of universal concern due to the increase of the paces of globalization, leading to disastrous changes in the spiritual and emotional spheres. Nevertheless, both are no longer able to leave the city, which has become attractive to them. This resonates with the views of the great Al-Farabi, who described the Baghdad as follows: "delightful and happy of the ignorant cities, appearance of which reminds a colorful and exuberant attire and due to this turns a favorite shelter for everyone, for every person in this city can satisfy his desires and aspirations. That's why people come (to this city), and settles there. Its sizes are increased immensely. People of different races are born there, there are different types of marriages and sexual relationships, children of various kinds, education and origin are born here. This city consists of diverse associations penetrating into each other with some parts differing from one another, where a foreigner does not stand out from the local population, and which combine all the desires and all the actions. Therefore, it is possible that over time worthy (people) can develop there. Sages and orators, poets of all kinds may exist there" (Al-Farabi, 1970), i.e., ignorant city where the cult of material, sex, power and money reigns, which is alien to the mentality of nomads.

Narrowing of the space is so detrimental that the first of them refers to the city directly with the word tar-kapas - cell, a prison, where he is a doll, and his soul is wandering in the steppe, and he, full of confusion, asks: quietly slipping along the stone streets, isn't my heart converting into a stone; and the second, having enumerated and rejected all the entertainment inherent in modern urban life, dreams of a child city, an angel, purity, innocence and sinlessness, that he finds at a small home $-y e l$.

Archisemes, differential and contextual semes of the given lexical and phraseological units are used by the authors to express the range of feelings, state of mind and reflect the impact of the urban bustle, rush, colour variety; theatrical fairground does not meet their expectations, imaginations, therefore perceived in a negative way. Negative connotation is related to the fact that the city lost "strong spatio-temporal relationship, which is fixed for thousands of years in the national consciousness," i.e., it's necessary "to know the benefits and dangers of space which you have chosen as the place of your residence and to correlate the phenomena occurring in this space with time to which they are confined" (Kaidarov, 1992), and time flies in the city, space is limited, and it changes the feelings, their perception and interpretation.

Since the concept of "city" is a complex multi-level construct, which reflects historical, sociological, cultural, mythological, philosophical ideas about the objects of reality, people living in it, then conceptualization of the city has its own core, circumnuclear area, close and distant periphery and its representation conveys cultural identity.

Of course, virtuous city and ignorant city about which Al-Farabi wrote, do not exist in its pure form, they are made as such due to perception, attitude, feelings, emotional state of people living in them.

Individually author's interpretation of the city image let us reveal its following increment meanings: city-height, city — dastarkhan, city — the cradle, city — paradise, city — beautiful future, city — tender girl, city — the secret world, city - hated civilization, ghost city, uncertainty city, cell city, angel city. These ideas are about the city where one feels odd and lonely, but another person can have beautiful feelings and it shows differences in the perception of each individual poet.

It is appropriate to recall that such perception and conceptualization of the city in the Kazakh literary discourse is not novel: Almost a hundred years ago, in 1918, when the relocation of the indigenous population in the city was negligible and urban processes developed not so rapidly as now, globalization remained far from our reality, Sultanmakhmut Toraigyrov, accused by the Soviet authorities as bourgeois poet, wrote a poem "Aitys." This unfinished poem as maleficent product, full of bay-nationalist ideology, was a long time in the list of banned literature and was rehabilitated only in the early 90 s of the last century. The reason for the prohibition of the poem is that the poet, using structural citation of the ancient genre of oral poetry, contrasted the steppe and the city, which at that time was a symbol of the new power, life. In fact, "Even at that time poet-citizen far sightedly predicted all the problems faced by today's generation. This is the fate of the people, problems of language, the tragedy of the Aral Sea, grave consequences of the Semipalatinsk test site, increase of the despiritualization sore in the heart of every citizen (Yespenbetov, 1993).

\section{Conclusion}

Thus, the image of the city in these texts is presented as the cause of the emergence of a new attitude to life, feelings, different perceptions of them, and ultimately all this leads to changes in behavior, character and mentality of the people. However, we cannot say that such a negative evaluation and rejection of modern civilization and urbanization processes are inherent in all the masters of the pen, the proof of this is a poem dedicated to the new capital of Kazakhstan-Astana, full of love, dreams, admiration and expectations. 
Of particular interest is verbalization and interpretation of the image of the city in the prose texts, because emotive meanings will be refracted in it in the structure of the characters and emotive meanings in the structure of the author, which mutually enrich, complement and complicate the perception of a particular image. This is important for the fact that in prose texts psychological (reserved in the subject), geographic (city, village (aul), nature), isolated (a house, room, patient room, transport) space have psychological and conceptual bases. In the description of the concept of "city" rich factual material can be provided by means of lyrics. In the future, attention should be paid to the texts of bilingual writers because the image of the city is verbalized differently in them than in the works of the poets who write in their native language, moreover, in this case, a different interpretation of these images by monolingual readers and bilingual readers can be observed.

\section{References}

Al-Farabi. (1970). A tractate on the views of the residents of the virtuous city. In Philosophical tractates. Alma-Ata.

Balmagambetova, Z. T. (2013). Theory of literary translation: Integrative and conceptological aspect: Monograph. In Balmagambetova. Astana: Master Po.

Dosmukhamedov, K. (1991). Alaman. Almaty: Ana tili.

Gachev, G. (2002). National images of the world. In Central Asia: Kazakhstan, Kirghizia. Islamic Space. Moscow, M.: Publishing service.

Gackendorff, R. (1993). Semantics and Cognition. Cambridge.

Kaidarov, A. T. (1992). The cult of words of Turkic people. In Turkic studies (pp. 74-79). Baku.

Kamzabekuly, D. et al. (2013) National literature and traditional mentality. Almaty: ARNA.

Language Committee of the Ministry of Culture and Information of the Republic of Kazakhstan. (2008). Kazakh-Russian dictionary. Almaty: Dyke-Press.

Maslova, V. A. (2008). Modern trends in linguistics: A textbook (p. 272). M.: Publishing centre "Academia".

Ministry of Education and Science of the Republic of Kazakhstan. Institute of Linguistics named after A. Baitursynov. (1999). Dictionary of the Kazakh language. Almaty: Dyke-Press

Nogerbekov, B. (2010). City and village in modern Kazakh cinema: Two cultures, two heroes. Political science series, 1 .

Ozhegov, S. I., \& Shvedova, N. O. (1999). Dictionary of Russian language, Complemented (4th ed.). Moscow. M.: Azbukovnik.

Paducheva, E. V. (1996). Semantic research. In The semantics of tense and aspect in Russian. The semantics of the narrative. Moscow, M.: Languages of Russian culture.

Phateyeva, N. A. (1995). Autocommunication as a way of the development of the text. Philological sciences, 2, 53-63.

Phateyeva, N. A. (2004). Counterpoint of intertextuality or intertext in the world of texts. M.: Agar.

Sattarov R. Kazakh society in the interior of demographic statistics. Rashid Sattarov.

Stepanov, Y. S. (1997). Constants. Dictionary of the Russian culture. In Research experience. Moscow, Shkola: Languages of the Russian culture.

Wierzbicka, A. (1996). Language. Culture. Cognition. Moscow.

Yanushkevich, A. (2006). Diaries and letters from a trip along the Kazakh steppe (p. 382). Pavlodar: EKO.

Yespenbetov, A. (1993). Creative biography of Sultanmakhmut Toraigyrov (Abstract of the doctoral thesis).

\section{Copyrights}

Copyright for this article is retained by the author(s), with first publication rights granted to the journal.

This is an open-access article distributed under the terms and conditions of the Creative Commons Attribution license (http://creativecommons.org/licenses/by/3.0/). 